\title{
Filozof NA PROWINCJI W UTWORACH PISARZY XIX WIEKU (WYBRANE ZAGADNIENIA)
}

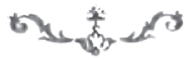

Filozofom dzisiejszym nie wierzę - będą oni sobie na katedrach systematyzować, ale jak kto silnie karabinem w ziemię uderzy albo grubo pieniędzmi brzęknie, natychmiast pokłonią się jemu całym narodem swoich mądrych głów, jak łan kłosów za wiatrem.

C. K. Norwid, List do A. Cieszkowskiego, Paryż, 1 marca $1871^{1}$

„Życie dostarcza więcej nauki, aniżeli kopy głów filozoficznych, pleśniejących między stosami książek".

B. Prus, Najnowszy dialog Platona ${ }^{2}$

PROWINCJA I PROWINCJONALIZM

$\mathrm{M}$ IMO IŻ POJĘCIA prowincja i prowincjonalizm nie znalazły swojego miejsca w fundamentalnym Słowniku literatury polskiej XIX wieku, są one, jak wiadomo, istotnymi kategoriami, dzięki którym można opisać literaturę romantyczną i pozytywistyczną ${ }^{3}$. Do literatury i kultury pierwszej połowy XIX wieku nurt prowincjonalizmu został wprowadzony przez twórców po-

1 Cyt. za: C.K. Norwid, Pisma wybrane, wyb. i oprac. J.W. Gomulicki, t. 5: Listy, Warszawa 1983, s. 661.

2 B. Prus, Najnowszy dialog Platona, w: tegoż, Pisma, t. 23: Nowele, opowiadania, fragmenty, t. 2, Warszawa 1949, s. 202.

3 Nie zostały też uwzględnione w znakomitym, „podręcznym” słowniku pozytywi- 
chodzących z tak zwanych kresów, czyli miejsc odległych od warszawskiego centrum, które wówczas było ośrodkiem twórczości klasycystycznej. Geografia miała swoje konsekwencje estetyczne - romantycy rozsadzili ramy istniejących przyzwyczajeń estetycznych żywiołem historyczności, potoczności i regionalności. Wskazuje na to Czesław Zgorzelski w swoim szkicu Regionalizm poezji romantycznej na ziemiach Rzeczypospolitej wielu narodów ${ }^{4}$.

Mając w pamięci w dużym stopniu regionalne tematy utworów romantyków (powieści litewskie, ukraińskie), można powiedzieć, że kwintesencją romantyzmu w literaturze polskiej jest apologia prowincjonalności i nobilitacja związanych z nią cech. W ówczesnych projektach cywilizacyjnych (tworzonych na przykład przez Adama Mickiewicza w prelekcjach paryskich) regionalność nie tylko nie była przeszkodą dla postępu, ale przeciwnie - duch prowincjonalizmu rozumianego jako przynależność narodowa i konkretna identyfikacja kulturowa gwarantował pożądany rozwój kultury i cywilizacji europejskiej.

Literatura drugiej połowy XIX wieku inaczej niż literatura romantyczna definiowała kategorię prowincjonalizmu 5. Mówiąc najogólniej, dokonujące się wówczas na ziemiach polskich przyspieszenie cywilizacyjne i recepcja zachodnioeuropejskich idei filozoficznych spowodowały rozdzielenie pojmowanego łącznie - na przykład w idei mesjanizmu - tradycjonalizmu (w tym przywiązania do religii) i postępowości. Nastąpiło wówczas również pęknięcie w spoistym do tej pory, szlachecko-prowincjonalnym rozumieniu polskości. Było to związane z postępującą industrializacją i zmianami, wymuszonymi w społeczeństwie przez represje postyczniowe (a przede wszystkim z narodzinami inteligencji). Romantyczna idea rozwoju, przychylna wobec przeszłości sarmackiej i umocowana w przestrzeni wartości etycznych i religijnych, po upadku powstania styczniowego ustąpiła miejsca kategorii postępu, opisującej modernizację rzeczywistości społecznej i opierającej aksjologię na fundamentach techniki, konsumpcji i naukowej weryfikowalności. Prowincja w rozumieniu pozytywistów (przynajmniej w publicystyce popularyzującej pozytywną filozofię i w początkowej, „zaangażowanej” fazie twórczości młodych) zaczęła oznaczać zastój i zacofanie, a na pewno brak

zmu, stworzonym przez Bogdana Mazana w pracy Pozytywizm warszawski z perspektywy mikroświatów tekstowych (Łódź 2002).

4 Cz. Zgorzelski, Regionalizm poezji romantycznej na ziemiach Rzeczypospolitej wielu narodów, w: tegoż, Obserwacje, Warszawa 1993, s. 244-272.

5 O rewaloryzacji kategorii prowincji - zob. L. Sadowski, Polska inteligencja prowincjonalna i jej ideowe dylematy na przełomie XIX i XX wieku. Na przykładzie guberni łomżyńskiej, suwalskiej i Białegostoku, Warszawa 1988. 
związku z centrum, z którym wiązano rozwój cywilizacyjny. Prowincjonalizm wpisany został tym samym w mentalny podział na awangardę i ariergardę ${ }^{6}$. Na marginesie można jedynie zwrócić uwagę, że taka kategoryzacja miała obosieczne, polityczne znaczenie. Ziemie polskie, $\mathrm{z}$ „centralną” Warszawą, z punktu widzenia Petersburga stanowiły przecież prowincję Rosji, co przekładało się na realne działania rosyjskich władz i kładło się cieniem na literaturze oraz świadomości społecznej obywateli „Priwislinskiego kraju”. Dodatkową komplikacją w rozumieniu pojęcia prowincjonalizm stanowił w tym czasie fakt, że wielu z pozytywistów po zakończeniu nauki w warszawskiej Szkole Głównej wracało do miejsc urodzenia lub też realizowało uniwersyteckie ideały, świadomie wybierając pracę organiczną z dala od centrum. Pisze o nich Stanisław Fita:

Wiele jednak inicjatyw wyszło od tych właśnie ludzi, którzy osiadłszy w różnych miastach i miasteczkach, usiłowali włączyć się do prac grona miejscowej inteligencji, ożywić najbliższe środowisko, podjąć konkretne roboty dla upowszechnienia wiedzy i rozwoju lokalnych instytucji życia społecznego. ${ }^{7}$

Zróżnicowane rozumienie prowincjonalizmu miało swoją analogię w podejmowanej przez pisarzy XIX wieku refleksji na temat filozofii jako nauki i jej społecznego usytuowania.

\section{LITERATURA I FILOZOFIA}

Problematyka wzajemnych powinowactw literatury i filozofii była podejmowana wielokrotnie w dwudziestowiecznej refleksji literaturoznawczej, czego wyrazem jest choćby praca zbiorowa Wypowiedź literacka a wypowiedź filozoficzna ${ }^{8}$. W jednym z zawartych w niej tekstów Janusz Sławiński definiował miejsca spotkania literatury i filozofii oraz wyróżniał trzy typowe sytuacje: przesunięcie dzieła filozoficznego w obręb literatury (i zastosowanie odpowiednich dla fikcji procedur czytania), odczytywanie z dzieła literackiego treści filozoficznych (rekonstrukcja „filozofii” pisarzy) oraz włączanie poszczególnych prądów literackich w kontekst intelektualny epoki, rodzaj filozoficznej bazy, nad którą zostały nadbudowane „światy przedstawione” 9 . Przegląd stanowisk historyków literatury wobec problematyki wzajemnych

$6 \mathrm{Na}$ „warszawskość” rozumianą jako zaprzeczenie prowincjonalności zwracał uwagę Bogdan Mazan (dz. cyt., s. 268 i n.).

7 S. Fita, Pokolenie Szkoły Głównej, Warszawa 1980, s. 91-92.

8 Zob. Wypowiedź literacka a wypowiedź filozoficzna, pod red. M. Głowińskiego i J. Sławińskiego, Wrocław 1982.

9 J. Sławiński, Posłowie zamiast wstępu, w: jw., s. 226-229. 
związków obu dziedzin zawiera artykuł Pawła Grafa Krytyka filozoficzna, zamieszczony w książce Literatura a filozofia, będącej zapisem konferencji naukowej z Poznania w 2008 roku $^{10}$. Autor tekstu wskazuje na przedmiotową i funkcjonalną odmienność wypowiedzi filozoficznej i literackiej, przemieszczając ich możliwą wspólnotę w sferę kompetencji czytelnika ${ }^{11}$.

Niewątpliwym argumentem na rzecz wzajemnych związków literatury i filozofii jest model lektury hermeneutycznej, który organicznie spaja obie dyscypliny. Czyni to jednak pod warunkiem kompromisu, na jaki muszą pójść literatura i filozofia; pierwsza - akcentując „zdarzeniowość” języka, druga - biorąc w nawias swą „naukowość”. Polem wspólnym dla spotkania, jak w ślad za lekturą Hansa-Georga Gadamera, Martina Bubera czy Michała Pawła Markowskiego sądzi Michał Januszkiewicz, jest kategoria doświadczenia, pozwalająca na transdyscyplinarne ujęcie procesu „lektury” ${ }^{12}$.

Przykładem naukowej konsumpcji związku literatury i filozofii jest praca Andrzeja Walickiego Filozofia polskiego romantyzmu, wprowadzająca w dyskurs z zakresu historii filozofii refleksję nad twórczością Adama Mickiewicza czy Cypriana Norwida ${ }^{13}$. Inaczej prezentuje tę problematykę Elżbieta Zarych w swojej książce Romantycy, myśliciele, inspiratorzy. Badania nad wpływem filozofii niemieckiej - od Kanta do Hegla - na literature polskiego romantyzmu ${ }^{14}$, ukazując przede wszystkim filozoficzne inspiracje polskiego prądu literackiego. Autorka tropi ślady obecności myśli Immanuela Kanta, Johanna Gottlieba Fichtego, Johanna Gottfrieda Herdera, Friedricha Wilhelma Josepha von Schellinga, Georga Wilhelma Hegla, a także "poetów filozofów”, Friedricha Schillera i Johanna Wolfganga Goethego, w utworach pisarzy polskich pierwszej połowy XIX wieku, a także w pracach literaturoznawczych poświęconych tej epoce. Sporządzony przez Elżbietę Zarych katalog odniesień służy raczej prezentacji różnic między filozofią i literaturą i nie rości sobie praw do interpretacji utworów literackich ze względu na ich teoriopoznawcze uwarunkowania.

Proponowany temat stanowi niewielką cząstkę powyższej problematyki.

10 P. Graf, Krytyka filozoficzna, w: Literatura a filozofia, pod red. B. Sienkiewicz i T. Sobieraja, Poznań 2010, s. 87-101.

11 Tamże, s. 101.

12 Zob. M. Januszkiewicz, Hermeneutyka jako miejsce spotkania filozofii i literatury, w: jw., s. $155^{-156 .}$

13 Zob. A. Walicki, Prace wybrane, pod red. A. Mencwela, t. 2: Filozofia polskiego romantyzmu, Kraków 2009.

14 Zob. E. Zarych, Romantycy, myśliciele, inspiratorzy. Badania nad wpływem filozofii niemieckiej - od Kanta do Hegla - na literaturę polskiego romantyzmu, Gdańsk 2010. 
Jednak wydaje się, że lektura skierowana na postaci filozofów jako bohaterów literackich ${ }^{15}$, umieszczonych $\mathrm{w}$ danym kontekście geograficznym i mentalnym, może określić wzajemne związki obu dyscyplin, a także ukazać recepcję filozoficznych nurtów dziewiętnastowiecznych i ich oddźwięk w świadomości pisarzy tej epoki. Obecne w twórczości Adama Mickiewicza, Józefa Ignacego Kraszewskiego, Bolesława Prusa, Adolfa Dygasińskiego czy Wiktora Gomulickiego odwołania do myśli Voltaire’a, Kanta, Hegla i filozofów pozytywistycznych są również sygnałem kulturowych i cywilizacyjnych przemian w społeczeństwie polskim, odnotowywanych przez ówczesną literaturę.

\section{KU ROMANTYCZNEJ „FILOZOFII NARODOWEJ”}

W pierwszej połowie XIX wieku dokonywała się na ziemiach polskich intensywna recepcja filozofii przede wszystkim niemieckiej - Kanta i Hegla, co wiązało się z przełomem romantycznym. Jednym z jego pierwszych sygnałów była twórczość Kazimierza Brodzińskiego, który swą świadomość literacką kształtował w kręgu niemieckiej filozofii i estetyki. Był między innymi tłumaczem Schillera, Goethego i Herdera, przebywał na uniwersytecie w Jenie. Rozprawa z 1818 roku O klasyczności i romantyczności tudzież o duchu poezji polskiej była próbą określenia zrównoważonego rozwoju literatury polskiej i pogodzenia jej naturalnego charakteru z poznanymi na Zachodzie nowymi prądami.

Dominację romantyzmu w literaturze polskiej poprzedziła dyskusja zwolenników nowego $\mathrm{z}$ klasykami. Finalnym akordem polskiego Oświecenia stała się polemika z myślą filozofa z Królewca; podjął ją niestrudzony propagator jasności umysłu i przejrzystości naukowego wywodu, znakomity matematyk i astronom Jan Śniadecki. Już samo miejsce, z którego rozległ się głos niechętny wobec Kanta, angażuje myślenie w kategoriach przestrzennego i kulturowego uwarunkowania filozofii. Dyskusja z autorem Krytyki czystego rozumu dobiegała bowiem z Wilna, miasta pogranicznego w imperium rosyjskim i jednocześnie żywo włączającego się w zachodnioeuropejską myśl naukową. Wypowiedź Śniadeckiego wywołała zresztą, o czym piszą autorzy pracy Recepcja filozofii Immanuela Kanta w filozofii polskiej w początkach XIX wieku ${ }^{16}$, reakcję między innymi ze strony jenajskiego cza-

Przykład takiej lektury daje Wiesław Ratajczak (Filozof jako bohater literacki. Trzy przykłady z Conrada, w: Literatura a filozofia, s. 179-189).

16 Recepcja filozofii Immanuela Kanta w filozofii polskiej w początkach XIX wieku, cz. 1: Józef Władysław Bychowiec, Anna z Zamoyskich Sapieżyna, Jan Śniadecki, Franciszek Wigura, red. T. Kupś, Toruń 2014. 
sopisma „Allgemeine Literatur-Zeitung”. Podstawowym argumentem tyrady wileńskiego uczonego było dążenie do uniwersalizmu i przekonanie o konieczności reprezentacji przez filozofię ponadregionalnych i ponadczasowych prawideł myślenia. Teorii Kanta uczony z Wilna nie uznawał w ogóle za filozofię, ale za marzycielstwo i zgubną metafizykę. Budziła ona opór - wychowanego na naukach Descartes'a, Gottfrieda Wilhelma Leibniza, Blaise'a Pascala czy d'Alemberta - matematyka przekonanego o cywilizacyjnej i naukowej niedojrzałości rodzimego kraju. „Prowincjonalność” ziem polskich miała być zdaniem Śniadeckiego nieodpowiednim miejscem dla recepcji filozofa z Królewca i mogła zaszkodzić niewykształconej jeszcze świadomości rodaków. Zwolenników filozofii niemieckiej uczony traktował jak intelektualnych kolonizatorów, szukających rynku zbytu dla nowych idei ${ }^{17}$. Pisał w swoim dziele O filozofii Kanta: „Powiedziałem w jednym z moich pism: że metafizyka w pewnym znaczeniu jest nauką ważną dla małej liczby głów już gruntownie uczonych i obdarzonych siłą rozległego rzeczy ogarnienia: ale najniebezpieczniejszą dla kraju zaczynającego się porządnie uczyć" ${ }^{18}$. Podjęta przez Śniadeckiego polemika z pismami Kanta trwała od 1814 do 1820 roku, budząc wiele emocji w środowisku naukowym ${ }^{19}$.

Przemiany w sposobie myślenia romantyków były związane ze znajomością najbardziej wówczas wpływowej filozofii Hegla. Obecność wielkiego berlińczyka jest w literaturze polskiej XIX wieku niemal powszechna. Odniesienia do stworzonej przez niego teorii są najczęściej negatywne, podejmowane z punktu widzenia narodowej tożsamości. Recepcję pism filozofa w polskiej prasie lat 1830-1850 przedstawił Adam $\mathrm{Bar}^{20}$. Odwołując się do takich tytułów, jak „Przegląd Naukowy”, „Athenaeum”, „Tygodnik Petersburski”, „Pielgrzym” czy „Gwiazda”, wskazywał na podstawowe argumenty przeciwników Hegla, jakimi były konieczność tworzenia polskich odpowiedników pojęć stosowanych przez niego i problemy natury religijnej. Pisał również o roli Edwarda Dembowskiego czy takich filozofów, jak Karol Libelt, czy August Cieszkowski, w propagowaniu systemu heglowskiego. Dla romantyków w do-

17 Tamże, s. 119.

18 J. Śniadecki, Pisma. O filozofii Kanta, Kraków 1821, bs.

19 Streszczenie poglądów Śniadeckiego na temat filozofii Kanta - zob. M. Baliński, Pamiętniki o Janie Śniadeckim, jego życiu prywatnym i publicznym i dziełach jego, Wilno 1865, t. 1, s. 848-868, przedruk: „Studia z Historii Filozofii” 2013, nr 4, http:// dx.doi.org/10.12775/szhf.2013.047 [dostęp 2016-09-21].

20 Zob. A. Bar, Zwolennicy i przeciwnicy filozofii Hegla w polskim czasopiśmiennictwie (1830-1850), w: Archiwum komisji do badania historii filozofii w Polsce, t. 5, Kraków 1933. 
bie intelektualnej dominacji myśli wielkiego berlińczyka (zapośredniczonego w dużej mierze przez Cieszkowskiego) palącą potrzebą stało się stworzenie filozofii narodowej, a więc w pewnym sensie prowincjonalnej. Ówczesne wartościowanie promowało raczej to, co swoiste, ukształtowane przez odrębną, etnicznie identyfikowaną historię i obyczajowość. W tym kontekście Hegel jawił się przede wszystkim jako autor koncepcji rozwoju cywilizacji europejskiej przeciwnej wobec samodzielnego bytu Polski i występuje jako negatywny „bohater” utworów literackich i publicystycznych.

Romantyczna literatura powstająca na emigracji w naturalny sposób zorientowana była na ogólniejsze aspekty funkcjonowania filozofii, nie była bowiem zakorzeniona $\mathrm{w}$ realiach życia polskiego w kraju. Operowała więc „idealistycznym” pojęciem polskości, wiążąc narodowość nie z instytucjami państwa (bo tego przecież nie było), a z poczuciem, emocjonalno-intelektualną konstrukcją opierającą się na tradycji, literaturze, pamięci historycznej (fundamentalną rolę odegrał w formacji umysłowej romantyków Maurycy Mochnacki, przekładający na polskie realia filozofię Schellinga). Mickiewicz w swoich prelekcjach paryskich podkreślał równorzędną rolę spekulatywnej filozofii swojego czasu i poezji; uważał, że choć podążają one różnymi drogami, osiągają podobny wynik - tak samo tłumaczą rozwój ludzkości i rolę Słowiańszczyzny. Swoje rozumowanie wykładowca opierał na refleksji poświęconej twórczości Kazimierza Brodzińskiego i koncepcjach Józefa Hoene-Wrońskiego.

Wymienione dwa przykłady: poety, krytyka literackiego, autora „miękkiej" koncepcji romantyzmu, widzącego w powstaniu listopadowym przebudzenie narodu oraz matematyka, który w swoich poszukiwaniach absolutu dotarł do idei mesjanizmu, posłużyły Mickiewiczowi do sformułowania narodowej filozofii, która związała historię, literaturę, naukę i religię w jedną całość. Paryski wykładowca, doceniając wizyjny charakter przekonań Wrońskiego, nie zgadzał się z jego ujemną oceną roli Francji w dziejach kontynentu. Dla Mickiewicza bowiem ogromne znaczenie miało miejsce, w którym mógł rozwijać swoje mesjanistyczne rozumowanie - poeta uważał ówczesny Paryż za centrum Europy nie ze względu jego zasługi na polu nauki i kultury, ale z racji dawanej ludom słowiańskim możliwości wypowiadania się na istotne dla ich poczucia narodowości tematy.

Postać Hoene-Wrońskiego, która posłużyła Mickiewiczowi do prezentacji teorii mesjanizmu, była również znana w Paryżu. Matematyk i filozof był bohaterem napisanej w 1834 roku przez Honoré de Balzaca powieści Poszukiwanie absolutu, w której pojawiły się echa głośnego procesu wytoczonego Hoene-Wrońskiemu przez bankiera z Nicei Pierre-Josepha Arsona. Pisma 
matematyka czytał również w 1852 roku Józef Ignacy Kraszewski, który w swoim Dzienniku z lat 1850-1853 zapisał uwagi na temat kresu filozofii uprawianej przez Niemców (czego wyrazem miała być właśnie koncepcja Hoene-Wrońskiego). Przebywający wówczas na Wołyniu autor Historii kołka w płocie, mając w pamięci - obok lektury filozoficznej matematyka (znanej zapewne z tłumaczeń Antoniego Bukatego z lat czterdziestych) - także prelekcje paryskie Mickiewicza, podobnie jak on uważał, że „Zachód jest w upadku, że Słowianie mają wielkie przeznaczenie, a jeżeli Zachód sam siebie nie poratuje, Północ go odrodzi. Starej Europie dosyć. Jest to konanie olbrzyma, co na ramionach dźwigał cywilizację lat tysiące i zmógł się, i chce odpocząć... Czeka go los Chin i Japonii” ${ }^{21}$.

Dokonana przez Mickiewicza w prelekcjach paryskich ocena filozofii Hegla wiąże się z interpretacją niedokończonego utworu Stefana Garczyńskiego Wacława dzieje. Jego autor został uznany przez wykładowcę za najlepszego znawcę koncepcji berlińskiego profesora, a poemat miał w ocenie Mickiewicza prezentować złudzenia filozoficznego umysłu co do natury świata i roli człowieka. Garczyński rzeczywiście odbywał studia filozoficzne w Berlinie w 1829 roku, podczas których słuchał (razem z autorem Pana Tadeusza) wykładów Hegla. Mickiewicz w swoich prelekcjach dokonał krytyki tej filozofii. Zarzucał uczonemu nie tylko fałszywe pojęcie chrześcijaństwa, ale także niezgodny z polską narodowością charakter koncepcji na temat rozwoju cywilizacji. Mówił w wykładzie trzydziestym:

Filozofia ta, o której nadmieniliśmy już w roku ubiegłym, ubóstwiająca człowieka, a w człowieku rozum ludzki, jako dowód zaś tego rozumu wskazująca dzieła ludzkie, dzieła zewnętrzne i widoczne - filozofia ta hołdowała powodzeniu i w rodzie niemieckim, zwłaszcza w królestwie pruskim, widziała najwyższy wyraz rozumu i siły człowieka, a tym samym najwyższy wyraz bóstwa. [...] Niektórzy zwolennicy tej filozofii powiadają wyraźnie, że wynalazek machiny parowej przyczynił się do postępu bóstwa. Bóstwo pojmują oni bowiem na sposób panteistyczny jako jestestwo rozległe i powszechne, które nie posiada jasnej świadomości swojej osobistości i musi rozdrabniać się na wiele duchów, wcielać się w ludzi, aby zdobyć świadomość nie tylko swej mądrości, ale nawet swojego bytu. ${ }^{22}$

W swojej refleksji na temat poematu Garczyńskiego Mickiewicz wskazuje na wyrażane w Wacława dziejach oskarżenie systemu Hegla o dyskredytowanie moralnej zasady bytu Polski i na prezentowaną przez poetę potrze-

21 J.I. Kraszewski, Dziennik z lat 1850-1853, w: tegoż, Pamiętniki, oprac. W. Danek, Wrocław 1972, s. 295-296.

22 A. Mickiewicz, Wykład XXX, w: tegoż, Dzieła, t. 9: Literatura słowiańska. Kurs drugi, przeł. L. Płoszewski, oprac. J. Maślanka, Warszawa 1997, s. 387-388. 
bę słowiańskiej filozofii, wyrastającej z wierzeń ludu i włączającej się w wiarę chrześcijańską, nieskłamaną przez naukę Kościoła.

Warunkiem powstania filozofii polskiej jest więc odrzucenie złudzeń dawanych przez zinstytucjonalizowaną religię i naukę, a zawierzenie geniuszowi narodowej duszy i zastąpienie słów czynem. Przykładem takiego czynu było dla Mickiewicza życie Garczyńskiego, które dodatkowo stanowiło dowód na to, jak filozofia może istnieć w formie narodowej, utożsamianej przez poetę z mesjanizmem. Można więc przyjąć, że dla Mickiewicza najwyższą formą filozofii słowiańskiej jest właśnie koncepcja ofiary i odkupienia ludzkości, którą rozumie następująco:

Ale czym w istocie będzie ów mesjanizm, ogłoszony i uznawany za narodowy przez filozofię i literaturę słowiańsko-polską? Czy mamy się spodziewać powstania na ziemiach polskich jakiejś szkoły filozoficznej? Czy to jakaś doktryna polska przeniesiona na Zachód? [...] Bynajmniej, nie takie jest posłannictwo narodu polskiego. [...] Doktryna, skoro tylko się sformułuje, staje się rzeczą martwą. Tym, co nie może się sformułować, tym, co jest, co trwa, co działa - jest sam człowiek, SŁowo wCielone. Takiego to męża przeczuli i przepowiedzieli poeci, których byliśmy tutaj wyrazicielami. ${ }^{23}$

Interpretacja utworu Garczyńskiego stanowiła podstawę wykładu Mickiewicza na temat mesjanizmu, który był dla niego zwieńczeniem filozofii dziewiętnastowiecznej, przejawiającym się w tożsamości słowa i czynu. Idee Hegla posłużyły poecie jako punkt odniesienia, który należało przezwyciężyć, odrzucając ograniczenia nakładane przez rozum, niczym w hymnie Akwinaty, w którym „co dla zmysłów niepojęte, niech dopełni wiara w nas”.

Krytykiem Hegla był również Zygmunt Krasiński. Wykształcenie filozoficzne autora Nie-boskiej komedii było rozległe, filozofię berlińczyka poznawał za pośrednictwem Victora Cousina. Krasiński jest nazywany poetą-heglistą, bowiem „przejął dialektykę Hegla w sprawach zasadniczych (teoria tezy, antytezy i syntezy), ale nigdy nie pogodził się z nim w kwestiach szczegółowych” ${ }^{24}$. W liście do Konstantego Gaszyńskiego pisał, negatywnie oceniając propozycje filozofa: „Przekleństwo tym Niemcom, panteistom i filozofom. [...] Przeklęci, przeklęci - oni mnie pozbawili na czas długi uczucia piękności”. [...] Ach, przeklęte Niemcy, filozofy" ${ }^{25}$.

Negatywny obraz filozofa $\mathrm{z}$ Berlina zawarł również w swoich utworach Kraszewski. Najpełniejszym wyrazem obecności Hegla w świadomości pisa-

A. Mickiewicz, Wykład XXXII, jw., s. 418-419.

24 H. Gradkowski, Etyka poety i etyka filozofa. Zygmunt Krasiński i August Cieszkowski, w: Kategorie etyczne w czasach upadku duchowości. Prace interdyscyplinarne, t. 8, red. i wstęp L. Rożek, Częstochowa 2011, s. 94.

Cyt. za: T. Pini, Dwaj poeci filozofowie. Szkic literacki, Lwów 1900, s. 17. 
rza jest artykuł Tadeusza Budrewicza Genotyp filozofa w wileńskich powieściach Józefa Ignacego Kraszewskiego ${ }^{26}$, który rekonstruuje obraz Wilna jako miejsca edukacji uniwersyteckiej i wszechstronnej inicjacji bohaterów twórczości autora Obrazów z życia i podróży. Badacz twórczości Kraszewskiego zajmuje się obrazem filozofa w imię przekonania o istotnym znaczeniu strukturalnym tej postaci dla wielu utworów Kraszewskiego oraz z powodu charakterystycznego napięcia, jakie wprowadza ten bohater pomiędzy świadomość teoretycznoliteracką Kraszewskiego a jego praktykę pisarską ${ }^{27}$. Budrewicz rekonstruuje również zainteresowania filozofią Kraszewskiego od utworów młodzieńczych, poprzez publikacje w „Tygodniku Petersburskim” i poszczególne powieści. Pisze:

Stosunek pisarza do berlińskiego filozofa zmieniał się. Na początku lat 40. Kraszewski nieufnie oceniał szerzenie się heglizmu w środowisku warszawskim. [...] Ale pisarz bronił Hegla i wskazywał jego inspirującą rolę dla filozofii współczesnej, kiedy przeprowadził gruntowną analizę krytyczną poglądów Trentowskiego. ${ }^{28}$

Z Bronisławem Trentowskim pisarz współpracował jako redaktor „Gazety Codziennej”, poświęcił mu też biogram w swoich Rachunkach z roku 1869, wskazując na zasługi filozofa, między innymi stworzenie przez niego polskiego języka filozoficznego ${ }^{29}$. W liście do Placyda Jankowskiego z 25 maja 1842 roku Kraszewski wypowiada się krytycznie o modzie na heglizm. Pisze, wyliczając współczesne sobie choroby intelektualne:

Trzeba wiedzieć, że Warszawa świeżo przez uczniów uniwersytetu berlińskiego zarażona została heglizmem, socjalizmem i demagogią w wysokim stopniu... Gdybyś też wiedział, co za dziwolągi tworzy ta młodzież, w której są indywidua nie bez wartości, nie bez talentu, ale zarozumiałe we dwoje swojego talentu..$^{30}$

W powieściach i wypowiedziach publicystycznych Kraszewskiego pojawia się zarówno uogólniona problematyka filozoficzna, wiążąca się z pojęciem postępu, jak i postać samego Hegla jako najbardziej wówczas wpływowego myśliciela, oddziałującego swoimi koncepcjami przede wszystkim na świadomość polskiej młodzieży. Pisarza interesował także kluczowy dla niemieckiego idealisty problem rozwoju, zmiany. Już od okresu wołyńskiego Kraszewski podejmował refleksję na temat rozkwitu cywilizacji ludzkiej

26 T. Budrewicz, Genotyp filozofa w wileńskich powieściach Józefa Ignacego Kraszewskiego, w: tegoż, O Kraszewskim. Studia, Kraków 2013, s. 223-262.

27 Tamże, s. 225-226.

28 Tamże, s. 236.

29 B. Bolesławita [J.I. Kraszewski], Rachunki. Rok 4. Z roku 1869, Poznań 1870, s. 651-658.

30 Cyt. za: Archiwum komisji do badania historii filozofii w Polsce, s. 162. 
i konsekwencji, jakie niesie ze sobą postęp techniczny ${ }^{31}$. Namysł ten towarzyszył dziełom pisanym jako efekt podróży po Europie Zachodniej aż do ostatnich powieści emigracyjnych ${ }^{32}$. Mówiąc najogólniej, pisarz podkreślał nieuchronność przemian cywilizacyjnych, zauważał jednak ich negatywne skutki dla życia rodzinnego, tradycji narodowych, odrębności poszczególnych nacji oraz dla poczucia podmiotowości ówczesnego człowieka. Nieobca była mu również krytyka politycznych konsekwencji dominacji zachodnioeuropejskiego modelu wiedzy.

Konfrontacja „prowincjonalnej” polskiej świadomości z filozofią europejską dokonuje się na kartach wydawanej w latach 1843-1844 Latarni czarnoksięskiej. Powieść powstała podczas pobytu Kraszewskiego na Wołyniu i prezentuje jak w soczewce obraz tamtejszej społeczności. Autor słowami swojego bohatera dokonuje oceny przydatności wykształcenia filozoficznego, odebranego w Niemczech. Fundamentalne dla światopoglądu romantycznego idealistyczne przekonania okazują się w recepcji polskiego szlachcica niepotrzebne i wręcz szkodliwe. Nie tylko nie służą życiu praktycznemu, ale prowadzą do poczucia społecznego wyobcowania.

Namysł nad rolą filozofii w poznaniu i w życiu społecznym pojawia się w Aktach babińskich, pisanych w tym samym czasie, co Latarnia czarnoksięska. Wyraźne odniesienie do legendarnej rzeczpospolitej babińskiej sugeruje, by wypowiedzi Kraszewskiego brać w cudzysłów, bowiem towarzyska republika powstała w podlubelskim Babinie, według wydanych w 1587 roku przez Stanisława Sarnickiego Annales, była karykaturą ustroju ówczesnej Rzeczpospolitej i służyła przede wszystkim rozrywce jej obywateli. Zygmunt Gloger w swojej Encyklopedii staropolskiej powtarza za Sarnickim:

Babińczycy [...] wybierali dla siebie: senat, biskupów, wojewodów, hetmanów, sekretarzy itd. Jeżeli ktoś mówił o rzeczach podniosłych, niemających związku z jego

31 Pisze na ten temat Tadeusz Budrewicz w artykule Mogiły - sprawa polska i pozaświat (w: Kraszewski. Poeta i światy, pod red. T. Budrewicza, E. Ihnatowicz, E. Owczarz, Toruń 2012, s. 440). W opinii Budrewicza Kraszewski w Wieczorach wołyńskich zarzucał Trentowskiemu osłabienie religijności w narodzie, współodpowiedzialność (z Heglem) za degradację kraju. Badacz wskazuje jednak, że Kraszewski i Trentowski znali się i szanowali. Na temat inspiracji filozofią niemiecką w twórczości Kraszewskiego - zob. I. Węgrzyn, „[...] gdy u nas wszystko na filozofia chorowało”. „Tomko Prawdzic" Józefa Ignacego Kraszewskiego jako zapis pokoleniowego doświadczenia romantyków, w: Krasiński i Kraszewski wobec europejskiego romantyzmu i dylematów XIX wieku, pod red. M. Junkierta, W. Ratajczaka, T. Sobieraja, Poznań 2016, s. 231-246.

32 Piszę o tym w swojej książce - zob. A. Czajkowska, „Poeci uczeni”. Związki nauki i literatury w twórczości romantyków, Częstochowa 2014; rozdz. Nauka dla ubogich? oraz Wobec cywilizacji rozumu (jeszcze o Kraszewskim). 
stanowiskiem, zostawał arcybiskupem babińskim; kto się jąkał, rzucał paradoksami lub prawił rzeczy niewiarygodne, tego mianowano mówcą lub kanclerzem [...]. Nominacje wydawano albo zaraz na miejscu podczas wesołej zabawy, albo wysyłano później na piśmie, opatrzywszy pieczęcią woskową. ${ }^{33}$

Odwołując się do Bachtinowskiej koncepcji kultury, można stwierdzić, że w Babinie dochodził do głosu porządek karnawału, podczas którego oficjalny świat stawał na opak, a wszelkie autorytety bywały otwarcie podważane i wyśmiewane.

W skład społeczności babińskiej wchodzili między innymi Mikołaj Rej, Jan Kochanowski i Mikołaj Sęp Szarzyński. W XIX wieku informacje o rzeczpospolitej podał na jednym z posiedzeń Warszawskiego Towarzystwa Przyjaciół Nauk ks. Franciszek Ksawery Szaniawski. O popularności republiki babińczyków w tym czasie świadczy satyryczne czasopismo „Pszonka”, wydawane początkowo w Strasburgu, potem (do 1844 roku) w Paryżu i nawiązujące swym tytułem do nazwiska właściciela Babina, Stanisława Pszonki.

Kraszewski wykorzystał semantykę babińską do krytyki swoich czasów i charakterystycznych dla nich mód naukowych. Jednym z jej elementów była rozprawa ze współczesną mu filozofią, a narzędziem - konfrontacja idei zaczerpniętych w Berlinie z realiami życia w prowincjonalnej Polsce. W zamieszczonym w pierwszym tomie tekście Filozofia pisarz dokonuje klasyfikacji osób uprawiających filozofię. Wyróżnia następujące rodzaje uczonych: filozofów nowoczesnych, młodych, zapatrzonych w ideały Heglowskie; filozofów tradycyjnych, przywiązanych do oświeceniowego kanonu z Voltairem i Jean-Jacques'em Rousseau ${ }^{34}$; tak zwanych filozofów domorosłych, nieposiadających gruntownego wykształcenia i żyjących w iluzji uprawiania nauki; filozofów religijnych oraz historiozofów. Ci ostatni zaprezentowani są poprzez określenia dotyczące czynności wykonywanych zwykle przez kobiety, mających w stylistyce Kraszewskiego zabarwienie ironiczne. Pisze autor szkicu:

Są jeszcze filozofowie, którzy, przeczytawszy kilka ksiąg o filozofii historii, marzą o sfilozofowaniu własnej krajowej historii. Na ten cel szyją jej kurteczkę z protestanc-

33 Z. Gloger, Encyklopedia staropolska ilustrowana, wstęp J. Krzyżanowskiego, Warszawa 1974, t. 1, s. 8 o.

34 Na temat współczesnej sobie filozofii francuskiej pisze Kraszewski w Pamiętniku: „Czytałem trochę o filozofii francuskiej i jej pracach teraźniejszych. Szkoła ta, jak ze wszystkiego widać, a najwięcej z jej prac nowych, systemu nowego nie utworzy. Jest to szkoła historyczno-krytyczna, trzymająca się na wodzy, by nie zgrzeszyć wyłącznością, z wskazówką, że wyłączność jest grzechem pierworodnym wszystkich systematów. [...] Oddajmy jednak sprawiedliwość Francji, wiele ona popularyzuje" J.I. Kraszewski, Pamiętniki, oprac. W. Danek, Wrocław 1972, s. 267-268. 
kich wykładów, fakta wywracają do zagranicznego kroju, i tak z francuska po niemiecku wystrojone dają nam bolesławowskie czasy, Polskę i Słowiańszczyznę przedchrześcijańską. [...] Niech sobie Kroniki [w]cale inaczej o ich charakterze i wypadkach czasowych świadczą - cóż to szkodzi? [...] Nie lepiejże od razu pełną jedności ulać historię, a czego brakuje, dosztukować, a co się sprzeciwia, wyrzucić?? Tym sposobem chcecie sobie wytłumaczyć całą historię na tle monarchicznym; wytłumaczycie ją łatwiuteńko; chcecie wyłożyć dzieje na tle republikańskim, cóż trudnego? [...] ot na przykład z jednej i tej samej historii, z jednych źródeł czerpanej, zrobić łyżkę dla dwóch przeciwnych stronnictw równie dogodną? [...] A co może być weselszego nad to filozofowanie nad historią, z powziętej myśli wprzód (a priori) dla osobistych potrzeb?? 35

Przenikliwa uwaga Kraszewskiego na temat możliwości interpretacyjnych tkwiących w dyskursie naukowym wyprzedza dwudziestowieczną teorię tropów Haydena White’a i znakomicie prezentuje krytyczny stosunek pisarza do koniunkturalizmu twórców określonych teorii naukowych.

Pisarz jest szczególnie wrażliwy na stwarzane przez współczesną mu filozofię pozory nowatorstwa, które okazuje się jedynie inwencją słowotwórczą, pozwalającą na produkcję coraz to nowych pojęć i terminów, niewnoszących nic nowego. Przykładem takiego sądu jest fragment drugiej części Akt babińskich, w którym ironia wobec pogoni za nowością przybiera kształt koncepcji uprawy buraków i kuriozalnych procesów zwiększania jej wydajności.

Kraszewski krytykuje również obecne w ówczesnej filozofii dążenie do dominacji jednego z systemów - heglizmu. Jest sceptyczny wobec możliwości stworzenia filozofii narodowej. W drugiej części Akt babińskich kpi z nadrzędnej idei narodowości w literaturze, sztuce itp., wskazując na bezwzględny wymiar piękna i prawdy. Pisze: „Filozofia zatem, jako dochodzenie prawdy, może się rozwijać w sposób narodowy, procederem umysłowym naszym, tak jak na przykład chleb może się u nas piec inaczej niż gdzie indziej, choć to będzie zawsze jeden chleb" ${ }^{36}$.

Kraszewski ujmuje prawdę osiąganą na drodze spekulacji umysłowych w kontekście możliwości wiedzy ludzkiej w ogóle. Przekonuje o złudzeniach wytwarzanych przez umysł: „Więcej wie jeden prorok przez Boga natchniony niż stu astronomów z teleskopami, chronometrami i tablicami najdokładniejszymi" "37. Jak postęp, nieumocowany na fundamentach wiary jest dla niego tylko ubóstwieniem zmiany, tak i filozofia (a także nauka w ogóle) niemająca praktycznego zastosowania dla dobra społecznego, jest jałowa. Ta

J. I. Kraszewski, Akta babińskie. Pismo nie-periodyczne i nie-zbiorowe, książeczka pierwsza, Wilno 1843, s. 30-31, 32.

Tamże, s. 69-70. 
teza pojawia się w twórczości autora Latarni czarnoksięskiej na marginesie rozważań o życiu i działalności Hipolita Cegielskiego, z którym pisarz spotkał się podczas swojego pobytu w Wielkopolsce w 1867 roku i któremu - po jego śmierci - poświęcił obszerny fragment swoich Rachunków z roku 1868. Postać nauczyciela i przemysłowca z Poznania jest dla Kraszewskiego wybitnym przykładem wykorzystania gruntownego wykształcenia humanistycznego, w tym znajomości filozofii heglowskiej, do działań prospołecznych i prorozwojowych. Przykład Cegielskiego jest znakiem możliwości połączenia dwóch odrębnych czynników ludzkiej aktywności: intelektualnej sprawności, wyrażającej się w spekulatywnym rozumowaniu i konsekwentnej pracy, wykorzystującej aktualne możliwości techniczne i gospodarcze do przeprowadzenia projektów cywilizacyjnych opartych na idei patriotycznej i poczuciu solidarności społecznej.

\section{FILOZOFIA NA PROWINCJI W PROZIE POZYTYWISTYCZNEJ}

Literatura polskiego pozytywizmu rozwijała się w dużej zależności od filozofii. „Młodzi”, walczący z dominującym romantycznym modelem kultury, zostali uformowani przez lektury Hippolyte'a Taine'a, Auguste'a Comte'a czy Johna Stuarta Milla, a na kształt pozytywistycznej antropologii miały wpływ przede wszystkim zdobycze nauk przyrodniczych i ścisłych, w tym teoria Charlesa Darwina. Naukowość filozofii tego czasu była mocno akcentowaną cechą dyskursu pozytywistycznego, często wymierzonego przeciwko metafizyce ${ }^{38}$. Poznawcze funkcje literatury pozwalały na stworzenie pojęcia „powieść filozoficzna” ${ }^{39}$, którym Eliza Orzeszkowa określała takie powieści Kraszewskiego, jak Sfinks czy Pamiętniki nieznajomego.

Wątków filozoficznych pełna jest twórczość Aleksandra Świętochowskiego (Dumania pesymisty, Wolter. W 10o-letnia rocznice jego śmierci, O epikureizmie, O powstawaniu praw moralnych) oraz Bolesława Prusa, który niejednokrotnie dawał wyraz swoim pozaliterackim zainteresowaniom. Postawy pisarzy drugiej połowy XIX wieku, wychowanych na filozofii pozytywnej i zapatrzonych w postępową odmianę refleksji na temat świata i człowieka oraz promujących sposób myślenia, w którym dominowały procedury wnioskowania wzięte z nauk przyrodniczych, kształtowały się odmiennie od przekonań romantyków. „Młodzi”, w dużej mierze absolwenci Szkoły Głównej, we „wstępującej” fazie pozytywizmu podejmowali się oceny społeczeństwa polskiego przy pomocy kryterium nowoczesnego światopoglądu. Zwykle nie

Zob. E. Paczoska, Krytyka literacka pozytywistów, Wrocław 1988, s. 103. 
była ona satysfakcjonująca. Ich zwrot ku europejskiej filozofii miał przede wszystkim, co oczywiste, przyczyny historyczne. Wynikał z poczucia klęski działań podejmowanych przez „starych” - romantyków.

Paradoksem pozostaje, że pozytywni apologeci nowoczesności i „europejskości” pochodzili w większości - podobnie jak ich literaccy poprzednicy - z prowincji (przybywali do Warszawy z Podlasia, Lubelszczyzny lub mieszkali - jak Orzeszkowa czy Konopnicka - poza stolicą) i ceną, jaką płacili za akces do nowoczesności, był swoisty gest wyparcia się tożsamości i jej związków z „krajem lat dziecinnych”. Dodatkowo zwrócić należy uwagę, że żywiołowej akceptacji nowej filozofii szybko zaczęło towarzyszyć rozczarowanie. Już w 1877 roku pisał Aleksander Świętochowski, „Poseł Prawdy”: "Ułożyliśmy i układamy miliony definicji ścisłych, żadna z nich jednak nie posiada praw nieomylności" ${ }^{4}$. Dumania pesymisty, z których pochodzi cytowany fragment, są wyrazem dramatycznego przesilenia ideałów pozytywistycznych ich najgorliwszego wyznawcy ${ }^{41}$.

Kreowana w początkowej fazie recepcji filozofii pozytywizmu tożsamość razem z postępowymi ideami realizowanymi przez literaturę służyła, jak sądzili wówczas „młodzi”, lepszej przyszłości narodowej. Miała przede wszystkim pobudzić intelektualny rozwój społeczeństwa, a wraz z nim podnieść moralność i gospodarkę uprawianą przez Polaków. Dlatego też w powieściach i nowelach pisarzy drugiej połowy XIX wieku pojawiały się postacie filozofów, umieszczanych na tle lokalnych społeczności i służących do prezentacji sądów, które w charakterystyczny sposób diagnozowały stan świadomości mieszkańców prowincji, a także - z drugiej strony - ukazywały zinfantylizowaną, powierzchowną recepcję europejskich koncepcji naukowych.

Prowincjonalizm w literaturze pozytywistycznej bywał identyfikowany jako przestrzeń pozawarszawska (tak jest choćby w utworach Prusa Na prowincji, Telegram na prowincja ${ }^{42}$ czy Elizy Orzeszkowej Na prowincji, w któ-

$$
\text { pod }
$$
tochowskiego, w: Noc. Symbol-temat - metafora, t. 2: Noce polskie, noce niemieckie,
pod red. J. Ławskiego, K. Korotkicha, M. Bajki, Białystok 2012, s. 468-47o. Inne rozumieniu XIX-wieczny, a ściślej mówiąc pozytywistyczny rodowód Świętochowskiego. Zdając sobie sprawę z niedoskonałości naukowego poznania i represyjnego charakteru przynajmniej niektórych norm społecznych, Poseł Prawdy nie utracił wiary w możliwość racjonalnej przebudowy życia publicznego. Był pozytywistą, a to znaczy: nie miał złudzeń, lecz ideały" (G. Borkowska, Pozytywiści i inni, Warszawa 1996, s. 62).

42 B. Prus, Na prowincji, w: tegoż, Pisma wszystkie. Humoreski, nowele, opowiadania, B. Prus, Na prowincji, w: tegoż, Pisma wszystkie. Humoreski, nowele, opowiadania, 
rym jednak występuje apologia wartości utożsamianych przez pozamiejską, adampolską społeczność), często były to realia galicyjskie. „Wielki świat Capowic”, jak zatytułował jedną ze swych powieści Jan Lam, oznaczał zespół cech mentalnych, które nie były akceptowane przez zwolenników światopoglądu naukowego, wierzących w postęp cywilizacyjny i kulturalny. Przykładem zaściankowej, kołtuńskiej mentalności galicyjskiej jest postać bohatera noweli Adolfa Dygasińskiego Filozof i praczka. Narzędziem krytyki koniunkturalizmu reprezentowanego przez Jana Szeląga jest wykonywana przez niego profesja. Bohater w wyniku awansu społecznego zajmuje stanowisko docenta w katedrze filozofii Uniwersytetu Jagiellońskiego. Dygasiński swoje oskarżenie wobec wykształconej części społeczeństwa (bohater jest związany $z$ domem profesora uniwersytetu i aspiruje do zajęcia jego stanowiska, ma mu w tym pomóc małżeństwo z córką profesora) opiera na kontraście efektownych formuł i realiów życiowych, a także na zróżnicowanym rozumieniu roli nauki. Utwór Filozof i praczka rozpoczyna się ustaleniami dotyczącymi istoty filozofii: „Co to jest filozofia? Jest to dociekanie prawdy w tym celu, aby się przekonać, że żadnej w ogóle prawdy nie ma. Albo: jest to powiązanie pewnych poglądów w taki system, któremu doświadczenie nieustannie przeczy" ${ }^{43}$.

Powyższy sąd na temat filozofii zostaje skonfrontowany przez Dygasińskiego z przekonaniem na temat jego społecznej przydatności. Pisze autor noweli:

Co to jest naiwność? Jest to szczere i głębokie przeświadczenie, że istnieje ogromna ilość świętych prawd, które uznawać należy, ponieważ są niezrozumiałe. Filozof wierzy, bo nie spostrzega, że mu życie przeczy. Naiwny wierzy, gdyż się przekonywa, że życie nie pokrywa jego wiary. W każdym razie człowiek własne ideały lepiej zna niż rzeczywistość i wyżej je ceni. ${ }^{44}$

Postać prowincjonalnego filozofa służy autorowi jako ilustracja tezy o nieprzydatności nauki utożsamionej z abstrakcyjnymi formułami, niepopartymi odpowiednią postawą etyczną. Jest narzędziem jednoznacznej krytyki zarówno mentalności, reprezentowanej przez społeczność Krakowa, jak i próżności bohatera, który uwierzył, że filozofia pojmowana jako znajomość określonych pojęć i systemów nie tylko pomaga w karierze życiowej, ale automatycznie

t. 1: 1864-1874, red. T. Żabski, oprac. T. Żabski, E. Lubczyńska-Jeziorna, H. Kubicka, A. Kuniczuk-Trzcinowicz, wstęp T. Żabski, Warszawa-Lublin 2014, s. 105-108; B. Prus, Telegram na prowincja, w: jw., s. 182.

43 A. Dygasiński, Filozof i praczka, w: tegoż, Pisma wybrane, pod red. B. Horodyskiego, t. 16: Nowele i opowiadania, Warszawa 1951, t. 4, s. 27.

44 Tamże. 
stwarza możliwość uczciwego i godnego życia. Przeczą temu podejmowane przez niego decyzje - uwiedzenie praczki, małżeństwo z córką profesora, wyrzeczenie się dziecka w imię kariery akademickiej, dostatku i prestiżu.

Filozofia zajmuje wiele miejsca w twórczości Bolesława Prusa, który miał przede wszystkim ambicje naukowe, często popularyzował współczesną wiedzę podczas odczytów, przyjaźnił się także i korespondował przez całe życie z psychologiem i filozofem Julianem Ochorowiczem. O sobie pisał: „[...] chorowałem na matematykę i filozofię" ${ }^{45}$. We wspomnieniach zgromadzonych przez Stanisława Fitę pisarz często bywa określany mianem filozofa ${ }^{46}$. Jego Najogólniejsze ideały życiowe bywają porównywane z twórczością Friedricha Nietzschego. O „konsekwentnym zanurzeniu twórczości Prusa w filozofii" pisze również Grażyna Borkowska ${ }^{47}$.

„Stosowana” wersja filozofii pojawia się u Prusa w Emancypantkach wraz $\mathrm{z}$ postacią jednego $\mathrm{z}$ bohaterów, nauczyciela geografii i matematyki, profesora Dębickiego oraz w opowiadaniach. Wykorzystanie filozofii w utworach Prusa jest bardziej skomplikowane niż tylko ukazanie jej przydatności wobec programu pozytywistycznego. Pisarz bowiem, sam mocno zainteresowany nauką współczesną, nadawał swoim bohaterom cechy intelektualistów i umożliwiał im skomplikowane dysputy światopoglądowe. Właściwie tylko jedno opowiadanie, Doktor filozofii na prowincji, można traktować jako trybut składany przez Prusa na rzecz społecznych powinności literatury pozytywistycznej ${ }^{48}$. Opowiadanie, którego akcja dzieje się w prowincjonalnym mieście nazwanym dyskretnie $\mathrm{X}$, przedstawia w krzywym zwierciadle zarówno groteskową realizację idei postępu, jak i potoczne przekonania na temat roli nauki oraz społecznej misji uczonego, jego swoistej pracy u podstaw. Mieszkańcy miasta, z zapałem poddający się edukacyjnej działalności doktora filozofii, pozytywistyczne hasło rozumieją jako „coś w guście poetyczno-filozoficznym, $z$ odcieniem postępowo-emancypacyjnym, a nawet

B. Prus, Kroniki, oprac. Z. Szweykowski, Warszawa 1955, t. 5, s. 335.

46 Tak pisze Wacław Horodyński: „Drugi z owych towarzyszy, ów «filozof», dostał od nas takie przezwisko z tej przyczyny, że niewiele od nas będąc starszym, imponował nam swoją szeroką już, mimo młodych lat, wiedzą. Tym filozofem był Aleksander Głowacki” - W. Horodyński, Prus w powstaniu styczniowym, w: Wspomnienia o Bolesławie Prusie, zebrał i oprac. Stanisław Fita, Warszawa 1962, s. 18. Podobne są wspomnienia Juliana Ochorowicza (tamże, s. 26-28).

47 G. Borkowska, Prusa filozofia życia, w: Jubileuszowe „żniwo u Prusa”. Materiały z międzynarodowej sesji prusowskiej w 1997 r., pod red. Z. Przybyły, Częstochowa 1998, s. 72.

48 Utwór został napisany w 1875 roku, drukowano go w odcinkach w „Kolcach” (od 6 lutego, nr 6-7, w numerze 8 dokończył je Aleksander Pajewski, w całości ukazało się w 1881 roku w Drobiazgach). 
zupełnie ateuszowskim, na przypadek jeżeli pan doktor ten tylko rodzaj filozofii uprawia" ${ }^{49}$.

Wprowadzając w senne życie prowincjonalnego miasta przybysza ze świata nauki pisarz ukazuje wyjątkowy status wiedzy akademickiej. Przyjazd uczonego powoduje pospolite ruszenie panien na wydaniu:

Jak wyżły za ptactwem, tak zdyszani, lecz zawsze poważni ojcowie rodzin biegali za Żydkami celem wyciśnięcia z nich niewielkich sumek pieniężnych na cały szereg mających nastąpić zebrań uroczystych. Dbałe o przyszłość córek matki wypytywały się przede wszystkim o cyfrę przybyłych, a następnie o to, czy proceder doktora filozofii zapewnia dostateczne utrzymanie. A córki?... Córki nie troszczyły się ani o cyfry, ani o procedery, lecz myślały tylko o tym, aby arcykapłanom wiedzy i sterownikom ogólnoludzkiej nawy ze skarbnicy swych serc i umysłów dziewiczych okazać jak największą ilość fizycznych i duchowych klejnotów. ${ }^{50}$

Mieszkańcy miasta na wieść o przyjeździe uczonego oczekują osoby niezwykłej, wykraczającej swoim zachowaniem poza przyjęte normy, niestandardowej i na sposób romantyczny twórczej, działającej pod wpływem nagłego natchnienia. Ich rozczarowanie budzi fakt, że doktor filozofii nie tylko nie jest permanentnie natchniony, nie konstruuje ad hoc nowych teorii naukowych, ale jest gotów rozmawiać o sprawach związanych z czynnościami życiowymi, takimi jak jedzenie czy spanie. Jego wygląd również nie spełnia społecznych oczekiwań ${ }^{51}$.

Nowela ośmiesza również wygórowane ambicje przedstawicieli nauki, których jedyną realizacją jest niezrozumiały język traktatów i abstrakcyjność, niepraktyczność podejmowanych problemów. Wszak przybywający na prowincję filozof jest autorem dzieła o stosunku świadomości do bezświadomości, wywołującego na prowincji tyleż ożywione, co jałowe w gruncie rzeczy dyskusje ${ }^{52}$.

B. Prus, Doktor filozofii na prowincji, w: tegoż, Pisma wszystkie. Humoreski, nowele, opowiadania, t. 3: 1875-1876, Warszawa-Lublin 2015, s. 257.

50 Tamże, s. 251.

51 Pisze Prus: „Przede wszystkim z niemałym podziwieniem dostrzeżono, że tenże doktor, członek itd. miał oblicze wcale pyzate i kark bodaj czy nie bernardyński i że na żadnej części ani swego ciała, ani swego ubioru nie nosił dyplomów, do których jego obszerna nauka, niepospolity talent pisarski i inne niemniej rzadkie a cenne przymioty niewątpliwie nadawały mu prawo. $Z$ nie mniejszym także zdziwieniem zaobserwowano, że tenże doktor itd. usiadł na krześle w sposób nader zwykły, wykazujący pewne cechy wspólne między nim a najpospolitszym prostaczkiem, i że bez śladu zakłopotania poprawił sobie cokolwiek przyciasny kołnierzyk tudzież obciągnął cokolwiek przykrótką kamizelkę" (tamże, s. 255).

52 Być może tematyka dyskusji filozoficznych była związana z przedmiotem obronio- 
Przekonanie o użyteczności filozofii dla życia pojawia się w noweli Prusa niejako w tle głównych wydarzeń, z powodu rozmowy dwojga marginalnych bohaterów na temat przybysza ze świata wielkiej nauki:

Pan Klinowicz nie jest doktorem zwyczajnym, ale doktorem filozofii...

- To on nie zapisuje recept?... [...]

- Doktor filozofii zapisuje recepty, ale tylko przeciw głupocie... [...]

- Przeciw głupocie - powiadasz pan?... Jakież to szczęście dla pana, że zejdziesz się z takim doktorem! ${ }^{53}$

Powyższe słowa, wypowiedziane przez niezaangażowaną w filozoficzne poruszenie staruszkę, można odczytywać jako stanowisko pisarza wobec portretowanej przez niego społeczności, dla której synonimem mądrości jest odpowiedni wygląd lub tytuł naukowy przed nazwiskiem. Postać przybysza $\mathrm{z}$ zewnątrz sygnalizuje również problematykę relacji osobowości wybitnej i społeczności, podejmowaną przez Prusa w różny sposób w wielu utworach literackich i publicystycznych ${ }^{54}$.

Refleksja nad statusem filozofii oraz jej użyteczności dla życia pojawia się także w noweli Filozof i prostak, w której pisarz zestawia logiczne reguły rozumowania $\mathrm{z}$ autentycznym dramatem człowieka. Skazany za nie swoją winę prostak przegrywa z filozofią zastosowaną na użytek władzy, dodatkowo popartą argumentami pieniężnymi. W efekcie biedak zostaje pozbawiony nie tylko swoich pieniędzy, ale jest skazany na obcięcie głowy. Gdyby znał filozofię, pojmowaną jako naukę manipulowania faktami, z pewnością jego los potoczyłby się inaczej.

Kanwą fabuły napisanej w 1873 roku noweli Filozof $i$ prostak jest ćwiczenie logiczne. Wiąże się ono zapewne $\mathrm{z}$ trwającymi od 1872 roku pracami

nej w 1874 roku - w rok przed napisaniem opowiadania Prusa - pracy doktorskiej Juliana Ochorowicza $O$ warunkach świadomości.

53 B. Prus, Doktor filozofii na prowincji, s. 264.

54 Pisze o tym m.in. Sylwia Karpowicz-Słowikowska: „Zagadnienie jednostki podejmował Prus wielokrotnie w twórczości beletrystycznej i publicystycznej. Najpełniej zrobił to w Najogólniejszych ideałach życiowych (pierwodruk prasowy 1897-1899, wyd. osob. 1901, 1905), gdzie pomieścił ostatecznie sprzeczne wobec siebie koncepcje. Z jednej strony apologizował jednostki silne, zdolne do oporu wobec despotyzmu duchowości zbiorowej, z drugiej strony opowiedział się za społeczeństwem jako organizmem, w którym preferencyjne miejsce przypada ogółowi. [...] «genialni ludzie» powinni być «mali i cisi». Wśród skromnych, niepozornych przebywali geniusze myśli, uczucia, woli. [...] Stanisław Wokulski, Madzia Brzeska, profesor Dębicki” - S. Karpowicz-Słowikowska, Niebłahy drobiazg. „On” Bolesława Prusa, „Wiek XIX. Rocznik Towarzystwa Literackiego im. Adama Mickiewicza” 2014, R. 7 (49), s. 151-152. 
Prusa nad książką Logika. Pierwsze zasady myślenia czy też Logika dla dzieci $w$ rozmowach. Pisarz wspomina o swoim zajęciu w liście do narzeczonej, Oktawii Trembińskiej, z 17 lipca 1872 roku. Autorka opracowania listów Prusa dodaje również informację o podejmowanych przez niego w tamtym czasie pracach nad tłumaczeniem Logiki Milla ${ }^{55}$. Przywoływana nowela jest krytyką filozofii, uprawianej w sposób wybiórczy i traktowanej jako uzasadnienie dla ludzkiej niegodziwości.

Przedstawiony w cytowanej wcześniej noweli Doktor filozofii na prowincji humorystyczny obraz społeczności miasteczka, postawionej wobec osoby z zewnątrz, naznaczonej statusem inności i niezwykłości, jest, obok doraźnych funkcji satyrycznych, także odbiciem problematyki, która zajmowała Prusa w sposób teoretyczny w Najogólniejszych ideałach życiowych. Filozoficzna praca autora Lalki była interpretowana przede wszystkim przez filozofów, ale jest także lekturą literaturoznawców, którzy widzą w niej zarówno próbę wypracowania przez Prusa naukowego światopoglądu, jak i kontekst dla pisanych przez niego utworów literackich.

Najogólniejsze ideały życiowe są odbiciem wczesnopozytywistycznych idei utylitaryzmu Milla i ewolucjonizmu Spencera ${ }^{56}$, a jednocześnie próbą zmierzenia się pisarza ze sposobem myślenia charakterystycznym dla przełomu antypozytywistycznego, który Maciej Gloger charakteryzuje jako „cały ferment myślowy, jaki zaistniał w wyniku kryzysu świadomości cywilizacyjnej i kulturowej XIX wieku, szczególnie silnie skonstatowanej zwłaszcza przez myślicieli niemieckich (Nietzsche, Dilthey, Burckhardt), a zwłaszcza - co z kolei silnie konstatowano we Francji - kryzysu myśli scjentystycznej, stanowiącej ważny składnik ideologii polskich pozytywistów" ${ }^{57}$.

Próba filozoficzna Prusa nie została doceniona przez czytelników, jej współczesna recepcja była, jak pisze Tadeusz Budrewicz, niewielka ${ }^{58}$. Przyczyny tego stanu wynikały, jak pisze badacz, z faktu, że Najogólniejsze ideały życiowe „były traktatem filozoficznym, zatem operowały pojęciami abstrakcyjnymi. Miały jednak ambicję dotarcia do jak najszerszego odbiorcy, więc były oparte na przesadnej wręcz liczbie przykładów i porównań. Były

Zob. A. Głowacki [B. Prus], Listy, oprac. i posł. K. Tokarzówna, red. Z. Szweykowski, Warszawa 1959, s. 45.

56 Zob. M. Gloger, Książka dla wszystkich i dla nikogo. „Najogólniejsze ideały życiowe” Bolesława Prusa wobec "filozofii życia”, w: Bolesław Prus. Pisarz. Publicysta. Myśliciel, red. M. Woźniakiewicz-Dziadosz, S. Fita, Lublin 2003, s. 382.

57 Tamże, s. 383.

58 T. Budrewicz, W sprawie „Najogólniejszych ideałów życiowych” Prusa-Głowackiego, w: jw., s. 367 . 
również programem działań polityczno-społecznych, musiały więc godzić uniwersalizm prawd naukowych z realiami codzienności, z aktualizowaniem bieżących wyzwań i potrzeb" ${ }^{59}$.

Tadeusz Budrewicz, biorąc pod uwagę kontekst historyczny pierwszych edycji dzieła (1897, 1901, 1905), akcentuje jego społeczne zaangażowanie i aspekt polityczny. Zaprezentowana w utworze Prusa filozofia pozostała jednak tylko wykładem teoretycznym, niewykorzystanym przez czytelników.

Zupełnie inaczej wygląda praktyczna przydatność nauki w powieści Emancypantki, w której wcieleniem filozofa jest uczący na pensji pani Latter profesor Dębicki. Uprawiana przez niego na marginesie właściwej pracy dydaktycznej filozofia wywołuje drwiny uczennic, ale budzi podziw pozytywnych bohaterów (Stefan Solski, Madzia Brzeska). Dębicki posiada umiejętność abstrahowania od drobiazgów i widzenia świata poprzez ogólne mechanizmy i prawidła rozwoju. Jest, jak pisze Tadeusz Budrewicz, figurą umysłową samego autora, nosicielem jego własnej wiedzy z zakresu nauk przyrodniczych i pozytywistycznej filozofii ${ }^{60}$, a także rozterek przez nie budzonych. Jednocześnie Dębicki nosi znamiona "genotypu” uczonego, będąc osobowością wybitną (ukazywaną wielokrotnie przez Prusa) i nieprzystosowaną do społeczeństwa. Pisze o nim Budrewicz, uzasadniając funkcjonalną obecność profesora w świecie emancypantek:

Profesor konsekwentnie jest pokazywany jako zaprzeczenie przeciętności. Niemodne stroje i roztargnienie czynią go postacią sympatyczną, choć przy tym wskazują jego system wartości („być” a nie „mieć”) i „stoicką postawę mędrca”. Jego spowolnione ruchy, wielekroć akcentowane, są w planie realistycznym motywowane ciężką chorobą. [...] Dębicki to jednocześnie komizm i wzniosłość, życiowe safandulstwo i dyskretne wpływanie na losy innych. ${ }^{61}$

Prowincjonalny filozof, jakim jest nauczyciel, rozprawia nie tylko o potrzebie czynu skierowanego ku dobru społecznemu czy o ewolucjonistycznych hipotezach dotyczących powstania świata, ale i o nieśmiertelności duszy. Odbiorcami jego wykładów (uznawanych przez pierwszych czytelników i niektórych badaczy za fragmenty nieuzasadnione fabularnie ${ }^{62}$ ) są kolejno Solski, Madzia Brzeska i jej brat, Zdzisław. Już samo usytuowanie wykła-

Tamże, s. 370-371.

60 T. Budrewicz, Filozofia profesora Dębickiego sposobem analitycznym wyłożona, w: Prus i inni. Prace ofiarowane profesorowi Stanisławowi Ficie, red. J.A. Malik, E. Paczoska, Lublin 2003, s. 124.

61 Tamże, s. 102.

62 „System» Dębickiego, który Prus uważał za swoje poważne osiągnięcie, stanowi element obcy utworowi literackiemu, jest w lekturze trudny i nużący” - J. Kulczyc- 
dowcy wobec słuchaczy (którymi są: wchodzący w życie bogaty człowiek, dotknięty „chorobą duszy”, myśląca sercem „emancypantka” oraz młody adept wiedzy przyrodniczej, zmagający się ze śmiertelną chorobą) wskazuje na marginalność głoszonej teorii. Wszak Dębicki nie kieruje uniwersytecką katedrą, klepie biedę, funkcjonuje na obrzeżach świata, w którym przyszło mu żyć. A niefikcyjni odbiorcy jego wykładów - czytelnicy utworu Prusa - znajdują się również na obrzeżach „obiektywnej” nauki, rządzącej się nie fantazją i zdolnością kreacji, a logiką sprawdzalnych faktów i niepodważalnych reguł. „Prowincjonalna” filozofia w twórczości autora Emancypantek jest bliższa życiu i bardziej użyteczna niż akademickie spekulacje czy książkowa mądrość. Takie też obserwacje prezentuje Wiktor Gomulicki, autor powieści dokumentującej zmierzch filozofii pozytywnej i rozwijającą się fascynację twórczością Arthura Schopenhauera i Friedricha Nietzschego ${ }^{63}$. W Złotych ogniwach, ukazujących świat warszawskiego mieszczaństwa, widać wyraźnie dystans do filozofii, wynikający z praktyki życiowej. Świadczy o tym rozmowa prowadzona w salonie:

Od najmłodszych lat babrał się w filozofii, a to nie tuczy. [...] Niechby uprawiał heglizm albo spinozyzm... uszłoby to jeszcze człowiekowi, który ma w perspektywie kilkakroć. Ale on męczy siebie i innych pesymizmem! On jest pesymistą z safandulstwa! Gdyby wstawał, jak ja, o piątej, przez cały dzień ganiał konno i musiał od rana do nocy ujadać się z ekonomem, pachciarzem, szynkarzem, fornalami, babami i Żydami, zaraz by pesymizmy z głowy mu wywietrzały! ${ }^{64}$

Do sprawdzenia praktycznej wartości prawd filozoficznych dochodzi również na wsi, gdzie przenoszą się bohaterowie powieści Gomulickiego. W Borkach mają oni możliwość słuchać wykładów filozofa, profesora Dębickiego, który jest wyraźnym nawiązaniem do Emancypantek Prusa ${ }^{65}$ i który, podobnie jak poprzednik, podaje w wątpliwość materialistyczne przekonania. Jednak nie w wykładzie prowincjonalnego uczonego, który wierzy w metody rozumowe, tkwi sedno mądrości życiowej. Jej nośnikiem okazuje się doświadczenie i uczucie, czego dowodzą losy bohaterów powieści. Oka-

ka-Saloni, Bolesław Prus, Warszawa 1975, s. 423. Obszerne sprawozdanie z opinii krytyków daje Tadeusz Budrewicz (Filozofia profesora Dębickiego..., s. 97-100).

63 Związki poetyckiej twórczości Gomulickiego z filozofią dokumentuje m.in. Tomasz Markiewka w artykule Poezja a filozofia. O dwóch wierszach Wiktora Gomulickiego (w: Wiktor Gomulicki znany i nieznany, pod red. B. Burdzieja i A. Stoffa, Toruń 2012, S. 129-152).

64 W. Gomulicki, Złote ogniwa, t. 1, Warszawa 1895, s. 120-121.

65 Zob. B. Bobrowska, Profesor Dębicki w Borkach (Wiktor Gomulicki i Bolesław Prus), „Wiek XIX” 2014, R. 7 (49), s. 191-206. 
zuje się bowiem, że na szczęście dla człowieka filozofia ma niewielki wpływ na jego życie. Modny w ówczesnym świecie Schopenhauer szkodzi co najwyżej zdrowiu, zwłaszcza kobiecemu, o czym świadczy ironiczny fragment opisujący reakcję heroiny Złotych ogniw, Wacławy, na nauki Schopenhauera:

Jednocześnie widocznym było, że prócz częstej migreny, wysiłkiem umysłu wywołanej, innej szkody Schopenhauer jej nie sprawia. Przypisywała to tężyźnie swojego ducha, temu, że od lat najwcześniejszych dążyła do zrobienia z siebie un esprit fort. Był jednak i inny powód: wrodzona naturze kobiecej odporność na ból, zarówno fizyczny, jak moralny. ${ }^{66}$

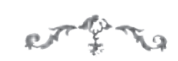

A B S T R A T

\section{The Philosopher in the Provinces}

\section{in the Works of $19^{\text {Th }}$ Century Writers (Selected Issues)}

The article suggests reading Polish literature of the nineteenth century with the focus on philosophers as literary heroes, functioning in a specific geographical and mental context. This perspective helps to identify the mutual relationships between both disciplines, and also allows one to point out particular registers of the reception of nineteenth century philosophical currents and the way they resonated in the minds of Polish writers of that era. The references Adam Mickiewicz, Józef Ignacy Kraszewski, Boleslaw Prus, Adolf Dygasiński, and Wiktor Gomulicki made in their works to the ideas of Voltaire, Kant, Hegel, and the positivist philosophers, are also a symptom of cultural and civilisational transformations in Polish society, recorded by contemporary literature.

\section{KE Y W O R S}

Adam Mickiewicz, Adolf Dygasiński, geopoetics, Boleslaw Prus, Bronisław Trentowski, Józef Ignacy Kraszewski, philosophy, Wiktor Gomulicki

W. Gomulicki, dz. cyt., s. 276. 